DOI

\title{
РОЗРОБКА КЛЮЧОВИХ ЕЛЕМЕНТІВ СИСТЕМИ РЕСУРСО- ТА ЕНЕРГОЕФЕКТИВНОСТІ
}

\author{
Соколова В.І., аспірант, Крусір Г. В., д.т.н, проф., \\ Шпирко Т. В., к.т.н, доц., Кузнєцова І. О., к.Т.н, доц., \\ Коваленко І. В. к.т.н., доц. \\ Одеська національна академія харчових технологій, м.Одеса
}

\begin{abstract}
Анотація. В сучасному світі, все більше користуються попитом готелі та ресторани. Це пов'язано з високою зайнятістю та активним життям сучасної людини. Вищезазначені заклади в процесі свого функиіонування несуть безповоротний вплив на довкілля. Проведені дослідження відкривають повну картину проблем, пов'язаних з функціонуванням готельно-ресторанного комплексу, серед яких вплив на атмосферу, гідросферу та літосферу; споживання ресурсів; накопичення твердих побутових відходів та ризики. В ході досліджень оцінено фактори, які впливають та спричиняють додаткове навантаження на довкілля. Для досліджуваного готельно-ресторанного підприємства сформована екологічна політика, впровадження якоі дозволить знизити негативний вплив підприємства завдяки формуванню організаційної, технічної та технологічної складової.

Проаналізовано та оцінено за бальною шкалою вплив готельно-ресторанного комплексу на навколишнє середовище методом релевантних таблиць або Матриць Леопольда.. Розроблено реєстр екологічних аспектів готельно-ресторанного комплексу, а саме вхідні, вихідні та ризикові; визначено підрозділи та процеси, які наносять значний вплив довкіллю. За результатами дослідження зроблено висновки, щзо суттєвий негативний вплив на довкілля наносять стічні води підприємства, які забруднені синтетичними миючими засобами. Визначено, щчо основними забруднювачами, щчо потрапляють у навколишнє середовище в процесі функиіонування готельно-ресторанного комплексу є фтор-, хлорорганічні сполуки. В роботі ідентифіковані екологічні аспекти підприємства та надані рекомендації щзодо поліпшення рівня екологічної безпеки готельно-ресторанного підприємства. В ході досліджень, визначено, шо готельно-ресторанне підприємство наносить на навколишнє середовище суттєвий негативний вплив.
\end{abstract}

Ключові слова: екологічна політика, аналіз життєвого циклу, А,В,С-аналіз, екологічні аспекти, матриці Леопольда, енергоефективність.

\section{DEVELOPMENT OF KEY ELEMENTS OF THE RESOURCE AND ENERGY EFFICIENCY SYSTEM}

\author{
Sokolova V., Krussir G., Shpyrko T., Kuznetsova I., Kovalenko I. \\ Odessa National Academy of Food Technologies
}

\begin{abstract}
In the modern world, hotels and restaurants are increasingly in demand. This is due to the high occupancy and active life of a modern person. The above-mentioned institutions in the process of their functioning bear irreversible environmental impacts. Studies conducted reveal a complete picture of the problems associated with the functioning of the hotel and restaurant complex, including the impact on the atmosphere, the hydrosphere and the lithosphere; consumption of resources; accumulation of solid waste and risks. In the course of the research the factors that influence and cause additional environmental burden are estimated. For the investigated hotel and restaurant enterprise the ecological policy is formed, the introduction of which will reduce the negative impact of the enterprise due to the formation of the organizational, technical and technological component. The influence of the hotel-restaurant complex on the environment by the method of relevant tables or the Leo-polda matrices is analyzed and evaluated.

The register of environmental aspects of the hotel-restaurant complex, namely input, output and risk, has been developed; Subdivisions and processes that have a significant impact on the environment are identified. According to the results of the study, it was concluded that significant environmental impacts of sewage water pollution, which are contaminated with synthetic detergents. It was determined that the main pollutants entering the environment in the process of functioning of the hotel-restaurant complex are fluoro-chloro-organic compounds. The work identifies the environmental aspects of the enterprise and provides recommendations for improving the level of environmental safety of the hotel and restaurant business. In the course of research, it was determined that the hotel and restaurant company has a significant negative impact on the environment.
\end{abstract}




\author{
Key words: environmental policy, life-cycle analysis, A, B, C-analysis, environmental aspects, Leopold's \\ matrix, energy efficiency.
}

Вступ. Формулювання проблеми. Готельно-ресторанний комплекс $є$ основною складовою туристичної галузі держави. Особливість організації роботи готельно-ресторанного комплексу — це високий рівень обслуговування відвідувачів, однак, функціонування даних комплексів потребує величезних енергетичних витрат та несе суттєвий негативний вплив на стан навколишнього середовища [1].

Організація технологічного процесу в ресторані як підприємстві виробництва кулінарної продукції при готелі має ряд особливостей, пов'язаних зі специфікою роботи. Вона полягає в поєднанні функції організації технологічного процесу приготування кулінарної продукції та ії реалізації. Продукція, яка випускається рестораном, швидко псується і вимагає швидкої іiі реалізації. В процесі приготування кулінарної продукції необхідно суворо дотримуватися правил санітарного режиму на виробництві, вести суворий контроль за якістю страв. 3 метою підвищення рівня якості та культури обслуговування, а також конкурентоздатності на світовому ринку, підприємства готельно-ресторанного бізнесу повинні пропонувати не лише високий рівень комфорту, але й широкий спектр додаткових послуг, які, зазвичай, потребують збільшення витрат енергетичних ресурсів [2,3].

Стабільне функціонування та зростання економічного потенціалу будь-якого підприємства в умовах ринкових відносин багато в чому залежить від наявності надійної системи ресурсо- та енергоефективності. Актуальність роботи визначається відсутністю системних досліджень 3 цього питання [2].

Одним із принципових моментів при вирішенні мети діяльності підприємств $\epsilon$ необхідність застосування інтегрованого підходу до збереження і раціонального використання природних ресурсів [1].

Доцільно та необхідно в процесі оцінки діяльності підприємств враховувати іх екологічний стан та вплив на навколишнє середовище, за допомогою розробки ресурсо- та енергоефективних систем, зокрема, відповідно до міжнародних стандартів ДСТУ ISO 14001: 2015 та ДСТУ ISO 50001: 2018.

Аналіз сучасних досліджень. Нагальною потребою сучасного розвитку країни є екологізація виробництва. Сьогодні під екологізацією розуміють процес поступового і послідовного впровадження систем технологічних, управлінських, економічних та інших рішень, які дозволяють підвищувати ефективність використання природних ресурсів і умов поряд з покращенням та збереженням якості природного середовища. Це одна 3 головних вимог сучасності в умовах глобальної екологічної кризи. В соціально-економічному плані екологізація повинна спиратися на перехід до природозберігаючих методів господарювання, а в технічному - на екологізацію технологій виробництва і природокористування. Під останнім слід розуміти сукупність заходів по запобіганню негативного впливу виробничих процесів на природне середовище [1].

Основні напрямки екологізації виробництва співпадають з головними прикладними завданнями екологічних технологій [2], а саме: розробка ефективних засобів очищення промислових, комунальних та тваринницьких стічних вод і промислових та транспортних викидів в атмосферу; заходи з проектування, які спрямовані на зменшення або повну ліквідацію шкідливих відходів, що забруднюють довкілля, перехід до використання замкнутих технологій, для яких характерна відсутність обміну речовин із зовнішнім середовищем; утилізація, тобто повторне використання відходів.

Регенерація первинних відходів, тобто залишення їх у циклі виробництва з метою додаткової переробки і вилучення невикористаних елементів або сполук, зокрема: повернення відходів у той самий виробничий процес з якого його отримано; використання відходів в інших виробничих процесах; використання у вигляді сировини для інших виробництв. Комплексну екологізацію виробництва доцільно реалізувати через екологізацію життєвого циклу продукції [5].

Проведено ряд досліджень $[2,3,4,6]$, задля вирішення проблеми енергоефективності закладів готельноресторанного бізнесу. Серед запропонованих рішень - перехід до будівництва екоготелів, які енергетично $\epsilon$ незалежними від держави та забезпечують себе альтернативними енергоресурсами (енергія сонця, вітру). Однак, для реалізація сталого розвитку підприємства потребує впровадження комплексу природоохоронних заходів та реалізації технологій захисту навколишнього середовища.

Основними завданнями дослідження $\epsilon$ аналіз життєвого циклу досліджуваного готельно-ресторанного комплексу, проведення А,B,C - аналізу, створення екологічної політики та пошук енергоефективних шляхів функціонування підприємства.

Матеріали досліджень. Аналіз життєвого циклу використовується, як основний інструмент отримання потрібної інформації про величину шкідливого впливу підприємства на довкілля, а також, як важливий інструмент екологічного аудиту і основний інструмент екологічного контролю, який забезпечує системне виявлення, оцінювання, зокрема, агрегування отриманих даних і віддзеркалення таким чином «екологічного успіху» чи «неуспіху» підприємства. Процес складання аналізу життєвого циклу, зазвичай, поділяють на чотири етапи, які представлені у таблиці 1. 


\begin{tabular}{|c|c|c|c|c|c|}
\hline \multicolumn{6}{|c|}{ Етапи складання аналізу життсвого циклу } \\
\hline Етап 1. Встановленн & \multirow{4}{*}{ 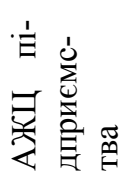 } & \multirow{4}{*}{ 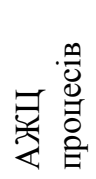 } & \multirow{4}{*}{ 灵录 } & \multirow{4}{*}{ 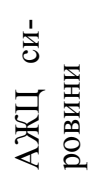 } & \multirow{4}{*}{ 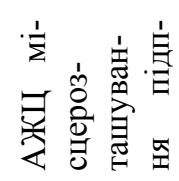 } \\
\hline Етап 2. Матеріальний баланс & & & & & \\
\hline Етап 3 Аналіз впливів на довкілля & & & & & \\
\hline Етап 4. Оцінка та заходи з покращення & & & & & \\
\hline
\end{tabular}

Це дозволяє визначити потребу в інвестиціях і санаційних заходах, тому є важливим складником для оцінювання ступеня ризику виникнення неординарних ситуацій, аспектів екологічної та іншої відповідальності і вартості підприємства[5].

Ідентифіковані та визначені кількісно екологічні аспекти використовуються в матеріальному балансі, в якому відображено матеріальні та енергетичні потоки, а також величини запасів як чинники входу, з одного боку, і відповідні чинники виходу - з іншого (табл. 2). Подану форму аналізу життєвого циклу можуть використовувати різні підрозділи підприємств і галузей $[1,4]$.

Вхідні та вихідні екологічні аспекти

Табличя 2

\begin{tabular}{|c|c|}
\hline \multicolumn{2}{|c|}{ Еко - баланс } \\
\hline Вхід: & Вихід: \\
\hline $\begin{array}{l}\text { - Нерухомість - земельні ділянки, будівлі; } \\
\text { - Основні виробничі засоби - виробниче облад- } \\
\text { нання, передавальні пристрої, транспортні засо- } \\
\text { би; } \\
\text { - Обігові засоби - сировина, матеріали, } \\
\text { напівфабрикати; } \\
\text { - Енергія - струм, мазут, природний газ; } \\
\text { - Вода - питна, технічна, дощова; } \\
\text { - Повітря - кількість і навантаження. }\end{array}$ & $\begin{array}{l}\text { - } \quad \text { Вихід продукції - напівфабрикати, готова } \\
\text { продукція; } \\
-\quad \text { Відходи - цінні відходи, рештки та інші; } \\
-\quad \text { Виділення енергії - струму, теплової енергії, } \\
\text { залишкової енергії; } \\
-\quad \text { Стоки - кількість, навантаження; } \\
-\quad \text { Відпрацьоване повітря - кількість, наванта- } \\
\text { ження; } \\
-\quad \text { Забруднення грунтів. }\end{array}$ \\
\hline
\end{tabular}

Відомий метод оцінки та ранжування впливів на навколишнє природне середовище, який широко використовується в екологічних дослідженнях - А,В,С - аналіз або матриці Леопольда. Перевагою цього методу $€$ простота, наочність і точність, що дозволяє виявити основні проблеми для їх ефективного вирішення; можливість виділити найбільш суттєві економічні аспекти природоохоронних рішень [7,8].

Виконана експертна оцінка окремих етапів дозволяє виконати загальну оцінку впливу кожного компоненту морфологічного складу відходів на компоненти довкілля протягом всього життєвого циклу готельноресторанного комплексу. Ступінь впливу компонентів твердих побутових відходів, а також стадії життєвого циклу чи екологічного аспекту оцінюють за сумою балів: А - вплив значний; $\mathrm{B}$ - вплив помірний; $\mathrm{C}-$ вплив незначний.

На основі політики в області екології сформована загальна корпоративна політика готельноресторанного комплексу (ГРК), що досліджується. Політика документально оформлена, затверджена генеральним директором готельно-ресторанного комплексу, доведена до відома всього персоналу підприємства та доступна для суспільства. До основних тез екологічної політики готельно-ресторанного комплексу відносяться: поєднання екологічних цілей і завдань з цілями і завданнями розвитку організації готельно - ресторанного комплексу в цілому; зниження негативної дії виробничої та іншої діяльності на навколишнє середовище; усвідомлене прийняття і активна підтримка екологічної політики і зобов'язань керівництвом готельно - ресторанного комплексу; ставити і виконувати конкретні екологічні завдання, що направлені на постійне покращення системи екологічного менеджменту і на зменшення дії на навколишнє середовище; оцінювати досягнутий ефект, із залученням незалежних експертів; вести роботу таким чином, щоб діяльність була соціально значимою і відповідала вимогам законодавства; підтримувати високий рівень обізнаності працівників про те, яку дію надає діяльність організації на навколишнє середовище в штатному і аварійному режимах; підвищення ефективності використання енергетичних і природних сировинних ресурсів; виробництво екологічно безпечної продукції; відкритість екологічної діяльності і співпраця із зацікавленими сторонами в області охорони навколишнього середовища; основна ціль готельно - ресторанного комплексу полягає в тому, щоб охорона навколишнього середовища стала невід'ємною частиною бізнесу у короткостроковому та довгостроковому масштабах; скорочення викидів забруднюючих речовин в атмосферу, в стічні води, зменшення об'єму утворення відходів; забезпечення високого рівня екологічної культури робітників підприємства, шляхом їх централізованого навчання у питаннях охорони навколишнього середовища; постійна відпові- 
Одеська національна академія харчових технологій ІННОВАЦІЙНІ РІШЕННЯ ПРОБЛЕМ ЕНЕРГОЗАБЕЗПЕЧЕННЯ

дність законодавству та іншим нормативним документам у всіх видах діяльності підприємства; застосування виробничого обладнання, технологій та матеріалів, що впливають чи забезпечують екологічну безпеку, у відповідності з найкращими світовими стандартами.

Аналіз життєвого циклу дозволив ідентифікувати екологічні аспекти підрозділів підприємства, які можна поділити на: вхідні, вихідні та ризикові. Завдяки даному аналізу можливо визначити кількісні показники енергетичних витрат, що необхідні в процесі діяльності готелю та ресторану, а також побудувати систему енергоефективних рішень задля зниження навантаження на довкілля [4]. У табл.3 чітко окреслено основні екологічні аспекти, які формуються в процесі функціонування досліджуваного ГРК.

\section{Ресстр екологічних аспектів системи екологічного менеджменту ГРК}

\begin{tabular}{|c|c|c|c|c|}
\hline $\begin{array}{l}\text { Вид діяльності, } \\
\text { назва підрозділу }\end{array}$ & \multicolumn{2}{|c|}{$\begin{array}{c}\text { Технологічний процес, назва } \\
\text { обладнання, установки - } \\
\text { джерела утворення аспекту }\end{array}$} & $\begin{array}{c}\text { Екологічний аспект (викид, } \\
\text { скид конкретної забрудню- } \\
\text { ючої речовини, утворення } \\
\text { конкретного відходу та ін.) }\end{array}$ & $\begin{array}{c}\text { Вплив на навко- } \\
\text { лишнє середовище } \\
\text { (забруднення кон- } \\
\text { кретних компонен- } \\
\text { тів навколишнього } \\
\text { середовища) }\end{array}$ \\
\hline \multirow{4}{*}{$\begin{array}{c}\text { Приготування страв } \\
\text { (овочевий, м’ясний } \\
\text { холодний цехи ) }\end{array}$} & \multirow{2}{*}{\multicolumn{2}{|c|}{ Очищення, нарізка сировини }} & Сировинні відходи & \multirow{2}{*}{$\begin{array}{c}\text { Забруднення } \\
\text { грунтів }\end{array}$} \\
\hline & & & Пакувальні матеріали, тара & \\
\hline & \multirow{2}{*}{\multicolumn{2}{|c|}{$\begin{array}{c}\text { Миття сировини і викорис- } \\
\text { таного посуду }\end{array}$}} & Бруд, залишки грунту & \multirow{2}{*}{$\begin{array}{c}\text { Скиди в стічні } \\
\text { води }\end{array}$} \\
\hline & & & Синтетичні мийні засоби & \\
\hline \multirow{3}{*}{$\begin{array}{c}\text { Обслуговування } \\
\text { номерів, ресторану, } \\
\text { бару, конференц - } \\
\text { залів }\end{array}$} & \multirow{3}{*}{\multicolumn{2}{|c|}{$\begin{array}{c}\text { Прибирання номерів, бару, } \\
\text { конференц - залу, столиків в } \\
\text { ресторані }\end{array}$}} & Битий посуд, пляшки & \multirow{3}{*}{$\begin{array}{l}\text { Забруднення } \\
\text { грунтів }\end{array}$} \\
\hline & & & Зіпсовані меблі, тренажери & \\
\hline & & & Папір & \\
\hline \multirow[b]{2}{*}{ Хімчистка, пральня } & \multirow{2}{*}{\multicolumn{2}{|c|}{$\begin{array}{c}\text { Хімчистка та прання одягу } \\
\text { та білизни }\end{array}$}} & Вуглеводні & \multirow{2}{*}{$\begin{array}{c}\text { Скиди в стічні } \\
\text { води, викиди в } \\
\text { атмосферу }\end{array}$} \\
\hline & & & Синтетичні мийні засоби & \\
\hline $\begin{array}{c}\text { Миття посуду } \\
\text { (м'ясний, холодний, } \\
\text { гарячий цехи) } \\
\end{array}$ & \multicolumn{2}{|c|}{ Миття забрудненого посуду } & Синтетичні мийні засоби & $\begin{array}{c}\text { Скиди в стічні } \\
\text { води }\end{array}$ \\
\hline Душові кабінки & \multicolumn{2}{|c|}{$\begin{array}{c}\text { Прийняття душу персона- } \\
\text { лом, відпочиваючими }\end{array}$} & Синтетичні мийні засоби & $\begin{array}{c}\text { Скиди в стічні } \\
\text { води } \\
\end{array}$ \\
\hline \multirow{8}{*}{$\begin{array}{l}\text { Автомобільна } \\
\text { стоянка }\end{array}$} & \multirow{8}{*}{\multicolumn{2}{|c|}{ Робота та миття автомобілів }} & Викиди CO2 & \multirow{3}{*}{$\begin{array}{l}\text { Викиди в } \\
\text { атмосферу }\end{array}$} \\
\hline & & & Викиди $\mathrm{NxOy}$ & \\
\hline & & & Викиди парів бензину & \\
\hline & & & $\begin{array}{c}\text { Пролив паливно - } \\
\text { мастильних матеріалів }\end{array}$ & \multirow{4}{*}{$\begin{array}{l}\text { Забруднення } \\
\text { грунтів }\end{array}$} \\
\hline & & & $\begin{array}{c}\text { Відходи паливно - } \\
\text { мастильних матеріалів }\end{array}$ & \\
\hline & & & Старі шини та акумулятори & \\
\hline & & & Відпрацьовані запчастини & \\
\hline & & & $\begin{array}{l}\text { Змиті паливно - мастильні } \\
\text { матеріали }\end{array}$ & $\begin{array}{c}\text { Скиди в стічні } \\
\text { води }\end{array}$ \\
\hline Котельня & \multicolumn{2}{|l|}{ Робота котельні } & Викиди СО2 & $\begin{array}{c}\text { Викиди в } \\
\text { атмосферу }\end{array}$ \\
\hline $\begin{array}{c}\text { Холодний, гарячий } \\
\text { цехи }\end{array}$ & \multicolumn{3}{|c|}{ Ризик вибуху посудин під тиском } & $\begin{array}{c}\text { Викиди в } \\
\text { атмосферу, скиди в } \\
\text { стічні води }\end{array}$ \\
\hline Транспортний цех & Робота автомобілів & & $\begin{array}{l}\text { Ік виникнення течі паливно - } \\
\text { мастильних матеріалів }\end{array}$ & $\begin{array}{l}\text { Скиди в стічні } \\
\text { води } \\
\text { Забруднення } \\
\text { грунтів }\end{array}$ \\
\hline $\begin{array}{l}\text { Овочевий, м'ясний, } \\
\text { холодний та гарячий } \\
\text { цех }\end{array}$ & Холодильники & & Ризик псування сировини & $\begin{array}{l}\text { Забруднення } \\
\text { грунтів }\end{array}$ \\
\hline
\end{tabular}


Аналізуючи екологічні аспекти та їх вплив на навколишнє середовище, виділяємо основні висновки, що потужний негативний вплив ГРК припадає саме на грунти та водне середовище. Відходи паливноенергетичних ресурсів, а також ризик виникнення течі паливно-мастильних матеріалів є основними чинниками забруднення літосфери.

Стічні води підприємства контаміновані з синтетичними миючими засобами, брудом мінерального походження, залишками грунту, розчином паливних і мастильних матеріалів та заражені мікробіологічною складовою. Узагальнюючи вищезазначене, можна констатувати, що негативний вплив спричиняють такі підрозділи. як кухня, пральня та хімчистка.

Таблиия 4

Оцінка впливу ГРК на навколишнс середовище

\begin{tabular}{|c|c|c|c|c|c|c|c|c|c|c|c|c|c|c|}
\hline \multirow[b]{2}{*}{$\begin{array}{l}\text { Сумарний вплив } \\
\text { на елементи до- } \\
\text { вкілля }\end{array}$} & \multicolumn{7}{|c|}{ ТПВ } & \multicolumn{5}{|c|}{ стадії ЖЦ } & \multirow[b]{2}{*}{ 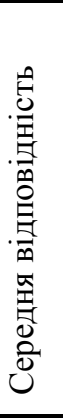 } & \multirow[b]{2}{*}{ 焉 } \\
\hline & 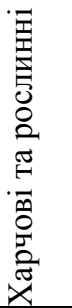 & 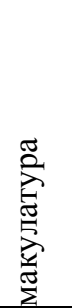 & 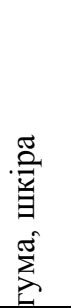 & 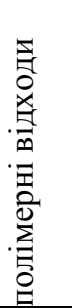 & 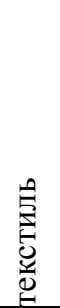 & 茎 & 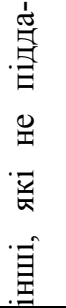 & 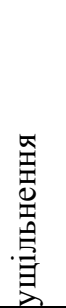 & 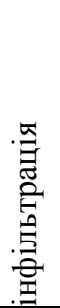 & 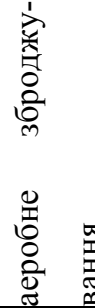 & 氛 & 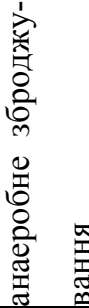 & & \\
\hline Повітря & 105 & 100 & 92 & 84 & 95 & 75 & 43 & 43 & 24 & 102 & & 81 & 71 & $\mathrm{C}$ \\
\hline Вода & 95 & 54 & 54 & 43 & 52 & 75 & 58 & 50 & 100 & 74 & & 55 & 71 & $\mathrm{C}$ \\
\hline Грунти & 99 & 82 & 115 & 90 & 107 & 104 & 101 & 79 & 99 & 71 & & 68 & 78 & $\mathrm{C}$ \\
\hline Твердий залишок & 14 & 22 & 40 & 40 & 40 & 19 & 40 & 35 & 14 & 19 & & 19 & 76 & $\mathrm{C}$ \\
\hline $\begin{array}{l}\text { Споживання ре- } \\
\text { сурсів }\end{array}$ & 42 & 42 & 32 & 32 & 32 & 32 & 26 & 45 & 29 & 29 & & 19 & 72 & $\mathrm{C}$ \\
\hline Інше & 35 & 20 & 20 & 22 & 20 & 37 & 22 & 20 & 25 & 22 & & 17 & 33 & $\mathrm{C}$ \\
\hline Ризик & 25 & 20 & 20 & 30 & 20 & 17 & 15 & 27 & 22 & 50 & & 50 & 60 & $\mathrm{C}$ \\
\hline Відповідність & 401 & 318 & 333 & 301 & 329 & 337 & 285 & 264 & 299 & 378 & & 290 & 401 & \\
\hline Оцінка & A & A & A & A & $\mathrm{A}$ & $\mathrm{A}$ & B & B & B & A & & $\mathrm{B}$ & A & \\
\hline
\end{tabular}

Екологічні впливи оцінено за допомогою А,В,C - аналізу [8] та представлено у вигляді матриць Леопольда (табл.4). До впливів, на повітряне середовище, які розглядались відносяться: $\mathrm{CO}_{2}$-екв., $\mathrm{CO}, \mathrm{NOx} \mathrm{SO}_{2}$, $\mathrm{CH}_{4}, \mathrm{NH}_{3}$, зважені частинки, діоксини, відпрацьоване тепло, пара, фтор-, хлорорганічні. сполуки, НМЛОС; на водне середовище - БПК, ХПК, кислоти/луги, $\mathrm{N}\left(\mathrm{NH}_{3}+\mathrm{NH}_{4}^{+}\right)$, нітрати, нітрити, органічні. речовини, солі, важкі метали, зважені частки.

Серед чинників, що впливають на грунти - БПК, ХПК, кислоти/луги, $\mathrm{N}\left(\mathrm{NH}_{3}+\mathrm{NH}_{4}^{+}\right)$, нітрати, нітрити, органічні. речовини, солі, важкі метали, зважені частки, оцінено вплив твердого залишку, споживання ресурсів, ризики та інше.

Можна зробити висновок, що в процесі функціонування готельно-ресторанного комплексу найбільшому забрудненню піддаються два компоненти довкілля, а саме, вода та грунти. Основними забруднювачами, які потрапляють у водне середовище, є органічні речовини. Стічні води містять зважені сполуки та механічні забруднення. Найбільш суттєвим вхідним екологічним аспектом для пральні, миття посуду та обладнання, побутових потреб, є вода. В стічні води потрапляють органічні сполуки, солі, кислоти, луги та інші небезпе- 
чні речовини. Основними чинниками негативного впливу на літосферу, можна назвати галогеновмісні сполуки та відчуження грунтів. Забруднення повітря є несуттєвим. Основним забруднювачем компонентів довкілля $є$ фтор-, хлорорганічні сполуки. Оцінивши вплив твердих побутових відходів на компоненти довкілля, необхідно відмітити, що істотними факторами, є харчові та рослинні відходи, деревина, гума та шкіра, текстиль, макулатура та полімерні відходи. Всі ці чинники отримали оцінку А, як ті, що мають значний влив на навколишнє середовище.

Розглядаючи стадії життєвого циклу, можна відмітити, що найбільший вплив має анаеробне зброджування, оцінка якого, відповідає категорії А.

\section{Висновки:}

Оцінюючи вплив вхідної та вихідної сировини, споживання паливно-енергетичних ресурсів, стадій технологічного виготовлення продукції, підрозділів підприємства, аналізу життєвого циклу вхідних та вихідних екологічних аспектів функціонування готельно-ресторанного підприємства на навколишнє природнє середовище, можна зробити висновок, що дане підприємство в процесі своєї роботи несе суттєвий негативний вплив на компоненти довкілля і потребує оптимізації та систематизації основних процесів.

Розробка екологічної політики, можна зробити висновок, що вона відповідає усім екологічним та іншим вимогам. Підприємство зобов'язується викидати та скидати відходи згідно з встановленими державними нормами, а також постійно зменшувати кількість скидів, викидів і утворення твердих відходів.

Оцінка впливу готельно-ресторанного комплексу на навколишнє середовище свідчить про те, які саме впливи надає даний комплекс на навколишнє природне середовище. Проведений аналіз життєвого циклу дає можливість визначити, в яких підрозділах, яка сировина та джерела енергії використовуються, та які впливи чинить кожен підрозділ та кожна операція в цих підрозділах, а також підприємство в цілому.

Було ідентифіковано екологічні аспекти підприємства, зокрема, ризикові критерії, а також матриці впливу.

Значимість екологічних аспектів визначено за допомогою методу релевантних таблиць (А, В, С - аналізу). Визначено найбільш значні екологічні аспекти такі як скиди, що містять синтетичні мийні засоби та органічні речовини; викиди, які мають в своєму складі $\mathrm{CO}_{2}$, діоксини, пари бензину та відпрацьоване тепло, як фізичний забруднювач. Основний вплив на погіршення стану літосфери несуть галогеновмісні речовини, використання сільськогосподарських земель та відчуження грунтів.

Значним екологічним аспектом є відходи від основного виробництва, це пов'язано з утворенням значної кількості відходів, які доцільно утилізувати. Викиди та скиди від котельні та основного виробництва оцінено, як не суттєві.

\section{References:}

1. Krusir, G.V., Shevchenko, R.I., Rusyeva, Y.P., Kondratenko, I.P., Kraynov, I.P. (2014) navch. posib. dlya stud. VNZ: Tekhnolohiyi povodzhennya z vidkhodami, 304.

2. Bohdanowicz, P., Churie-Kallhauge, A., Martinac, I., Rezachek, D. (2001) Energy-efficiency and conservation in hotels-towards sustainable tourism. 4th International Symposium on Asia Pacific Architecture. Hawai $1,1-12$

3. Jacobs, G., Klosse, P. (2016) Sustainable restaurants: A research agenda. Research in Hospitality Management 6, 1, 33-36.

4. Yin P., Tsai, H., Wu, J. (2015) A hotel life cycle model based on bootstrap DEA efficiency. International Journal of Contemporary Hospitality Management, 5, 27, 918-937.

5. Kobushko, I.M. (2006) Ekolohizatsiya etapiv zhittyevoho tsiklu produktsiyi v sistemi ekolohizatsiyi promislovoho virobnitstva. Visnik Sums`koho derzhavnoho universitetu, 1, 85, 127-135.

6. Baldwin, C., Wilberforce N., Kapur A. (2011) Restaurant and food service life cycle assessmentand development of a sustainability standard. The International Journal of Life Cycle Assessment, 1, 16, 40-49.

7. Filimonau, V., Dickinson, J., Robbins, D., Huijberegts, M.A.J. (2011) Reviewing the carbon footprint analysis of hotels: Life CycleEnergy Analisis (LCEA) as a holistic method for carbon impact appraisal of tourist accommodation. Journal of Cleaner Production, 1-14

8. Sahdyeyeva, O.A., Krusir, H.V., Tsykalo, A.L. (2018) Doslidzhennya protsesiv kompostuvannya kharchovoyi skladovoyi tverdykh pobutovykh vidkhodiv. Tekhnohenno-ekolohichna bezpeka, 4,2, 13-23. DOI: 10.5281/zenodo. 1244572

Отримано в редакцію: 02.04.2019

Прийнято до друку: 12.06.2018
Received: 02.04.2019

Approved: 12.06.2018 